\title{
Follow-up of tibialis posterior transfer surgery (TPT) for drop-foot in leprosy
}

\author{
Yutaka ISHIDA*1), Saw LWIN ${ }^{2)}$, Kyaw MYINT ${ }^{3)}$ \\ 1)Bureau of International Cooperation, International Medical Center of Japan, \\ 2)Rtd. Orthopedic surgeon, National Yenanthar Leprosy Hospital, Mandalay, Union of Myanmar \\ 3)National Leprosy Control Programme, Department of Health, Union of Myanmar
}

[Received: 21 Jan. 2007 / Accepted: 28 April. 2007]

Key words : drop-foot, leprosy, Myanmar, tibialis posterior transfer surgery (TPT)

Prevention of Disability (POD) service needs to be expanded for future reducing the leprosy burden. Tibialis Posterior Transfer Surgery (TPT) is an established procedure and relatively easy to do at district level general hospitals. It can protect further damages of affected foot and consequently reduce patient's social burden as well. Totally 70 TPT surgeries were done during a joint project of JICA' on leprosy control and basic health service in Myanmar for training purpose (Jan/2002-Jan/2006). A follow-up assessment was done for exploring the effectiveness of foot drop surgery, in Nov/2006 at 9-selected townships in MidMyanmar. 33 cases (Male 22, Female 11) were reviewed and the mean of follow up period was 29.1 months ( $\mathrm{SD}=7.1,10-48$ months). Total results were; good: 25 cases (76\%), fair: 4 cases (12\%) and poor: 4 cases $(12 \%)$. In good and fair cases, patients were satisfied with the results and TPT improved the QOL of patients. In almost all cases $(32 / 33,97 \%)$ after TPT, patients are free from plantar ulcer. Most serious complication of operation (4 cases, 12\%) identified was inversion deformity due to loosed tension of lateral tail of grafted TP tendon sutured to Extensor Digitorum Longus. From the results of TPT surgery follow-up, it can benefit much to the patients if resources permit to make it as a routine service in more places.

\section{Introduction}

Leprosy is a chronic infectious disease, which

\footnotetext{
${ }^{*}$ Corresponding author :

Bureau of International Cooperation, International Medical Center of Japan, Ministry of Health, Labour and Welfare, 1-21-1, Toyama, Shinjuku-ku, Tokyo 162-8655, Japan.

TEL : +81-3-3202-7181 FAX : +81-3-3205-7860

E-mail :y-ishida@it.imcj.go.jp
}

affects mainly skin and peripheral nerves. It may cause serious permanent impairment of peripheral nerve, such as ulnar, medial and common peroneal nerve palsy"). Drop foot is a one of common deformities in leprosy caused by common peroneal nerve palsy, which sometimes makes patients' social and economic life difficult. Without proper treatment given, drop foot may cause broad destruction of affected foot and ankle joint, which can 
only be treated by below knee amputation. It often happened especially in countries where the prevention of disability (POD), as well as prevention of worsening disabilities (POWD) and rehabilitation services were not available in the past, such as Myanmar.

Leprosy elimination, which is defined as registered prevalence rate is below $1 / 10,000$, was achieved at national level at the end of January 2003 in Myanmar ${ }^{2)}$, and the following year the Government established three strategies for leprosy control beyond 2005. The prevention of disability (POD), as well as prevention of worsening disabilities (POWD) and rehabilitation became new one among these strategies ${ }^{2}$. Though the main principles of leprosy control will not change over the coming year, there is an urgent need to make decisive changes in the organization of leprosy control, in the attitude of health care providers and beneficiaries, and in the working arrangements between all partiners ${ }^{3,4}$. In the context mentioned above, Prevention of Disability (POD), as well as prevention of worsening disabilities (POWD) and rehabilitation services need to be expanded for future reducing the leprosy burden in the integrated way with general health services. There are more than 260,000 RFT (Release From Treatment) patients after WHO/MDT (Multiple Drug Treatment recommended by WHO) was introduced in 1991 in Myanmar. According to the baseline survey of disability done in 2003-2004 at 9 selected townships in Mid-Myanmar, about $8.4 \%$ of RFT patients got drop foot deformity ${ }^{3}$.

Tibialis posterior transfer surgery (TPT) is an established procedure for correction of drop-foot in leprosy ${ }^{5,6)}$ and relatively easy to do at district level general hospitals, with which patients can protect their foot from further damages and live their normal life in community. In Myanmar there was only one hospital, National Yenanthar Leprosy Hospital,
Mandalay, where this service was available during early 2000 's, because surgical interventions needed much human and financial resources.

A joint project of JICA and Department of Health, Union of Myanmar on Leprosy Control \& Basic Health Services (4/2000-3/2005) conducted a series of surgery trainings for reconstruction of various deformities in leprosy at National Yenanthar Leprosy Hospital, Mandalay and at general hospitals in 9-selected townships in Mandalay, Sagaing and Magway Divisions ${ }^{7}$. A follow-up assessment was done for evaluating the effectiveness of foot drop surgery, in Nov/2006 at 9-selected townships. This study shows the 2-3 year results of tibialis posterior transfer surgery (TPT) for drop-foot in leprosy done for training purpose in Myanmar.

' Japan International Cooperation Agency, which is a implementer of bi-lateral technical cooperation under Ministry of Foreign Affairs, Japan

${ }^{2}$ Workshop on Strategy for Leprosy Control beyond 2005, Yangon, Myanmar (31.5.04 to 2.6.04)

${ }^{3}$ Report under preparing $(\mathrm{N}=10,528)$

\section{Method of operation for training purpose}

In order to build up a surgical capacity for medical officers of Government hospitals on prevention of disability (POD), as well as prevention of worsening disabilities (POWD), the project conducted a series of surgery training for various of deformities and complicated plantar ulcers in leprosy. Among them totally 70 TPT surgery (Male: 53, Female: 17) were done for training purpose.

For almost trainees TPT surgery was the first practice and well-experienced consultant surgeons attended them all the time instructing every detail procedures.

Screening of TPT surgery candidates included following criteria; RFT patients, more than 12 
months history of complete common peroneal nerve paralysis (not able to make any foot-up movement; Tibial Anterior Muscle=0, Extensor Hallucis Longus Muscle $=0$, Extensor Digitorun Longus $=0$, Peroneal Group Muscles $=0$ in $\mathrm{VMT}^{4}$ ), Normal muscle strength of Tibial Posterior Muscle ( $\mathrm{TP}=5$ in $\mathrm{VMT}$ ), free of leprosy reactions more than 6 months, free of wound or ulcer at any part of body and high willingness of commitment for 3 month-long TPT surgery schedule ${ }^{8}$. Every individual patient and family member got clear informed consent before operation.

The method used was that tibialis posterior tendon transferred through either circum-tibial route or inter-osseous route to the tendons of hallucis longus and the extensor digitorum longus in the foot together with lengthening of the Achilles tendon. During training times, circumtibial rout was likely to be selected for relatively old aged case because of the likeliness of ossification of interosseous membrane and inter-osseous route was selected for younger cases. A 4 weeklong POP cast was applied before post-operation physiotherapy started. The nurses, who were called from the same hospital of the trainees, got necessary training at National Yenanthar Leprosy Hospital on pre and post physiotherapy for TPT surgery.

${ }^{4}$ Voluntary Muscle Testing

\section{Subjects}

33 cases (Male: 22, Female: 11) of post tibialis posterior transfer surgery (TPT) were evaluated in Nov. 2006, out of 70 cases (Male: 53, Female: 17) operated through the project activities (Jan/2002Jan/2006, coverage: 47\%). Right side of TPT: 18 cases, Left side of TPT: 15 cases Follow-up period: Male: Mean: 27.4 months ( $\mathrm{SD}=7.1$, Range: 10-38 months, Median: 26 months), Female: Mean: 34.4 months ( $\mathrm{SD}=8.1$, Range: $26-48$ months, Median: 29 months), Total: Mean: 29.70 months ( $\mathrm{SD}=8.1$, Range: 10-48 months, Median: 28 months)

\section{Method of follow-up}

Cases were called for assessment to each township capital and assessed by two senior surgeons who were supervisors at training times. Data collected besides personal ones were; 1 . Active range of both dorsi- and plantar-flexion, 2. Tension of grafted tendons, 3. Alignment of foot to lower leg, 4. Stability of ankle joint, 5. Skin condition of foot sole, 6. Posture of gait, 7. Patient's opinion about getting TPT surgery and change of QOL (Quality of Life) after surgery and 8 . Special remarks by examiners. 9. Overall impression of the present status by taking all the individual data into consideration, chosen from Good, Fair and Poor. "Good" is defined that there is much improvement of quality of life (QOL) after TPT operation, even if there may be some minor problems that do not affect QOL or do not cause further destruction of the foot. "Fair" is defined that there is some improvement of QOL but still has some minor problems, which may cause further problems. And "Poor" means that there are still major problems present for QOL, which probably cause further destruction of the foot in future.

\section{Results}

1. Active range of both dorsi- and plantar-flexion and total Range of Motion: shown as Table 1. and 2. 2. Tension on grafted tendons:

(1) Good and equally distributed: $21(64 \%)$

(2) Abnormalities: 12 (36\%)

1. EHL ${ }^{5}$ : Good, $\mathrm{EDL}^{6}$ : no tension: 3 and EHL: Good, EDL: less tension: 4,

2. EDL: strong, EHL: less tension: 3 
3. Both tendon: weak: 2

3. Alignment of foot to lower leg:

(1) Good, neither inversion nor evasion deformities: $26(79 \%)$

(2) Abnormalities: 7 (21\%)

1. Inverted deformity: 6 (18)

2. Fair due to wrong isolation exercise: $1(3 \%)$

4. Stability of ankle joint:

(1) Good: 29 (88\%)

(2) Fair: 4 (12\%)

(3) Unstable: 0

5. Skin condition of foot sole:

(1) Plantar ulcer free: 32 (97.0\%)

(2) One swallow ulcer on MP (Metacarpal-Pharangial) joint: $1(3 \%)$

6. Posture of gait

(1) Normal gait: 29 (88\%)

(2) Step gait (slight): 4 (12\%)

7. Patient's opinion about getting TPT surgery and change of QOL after surgery Remarks:

(1) QOL improved and satisfied with surgery result: $29(88 \%)$

(2) He can drive a car after surgery: $1(3 \%)$

(3) Neuralgic pain: 2 (on r-knee-ankle: 1, along transferred tendon and r-medial malleorus: 1)

8. Remarks by examiners

(1) Need of re-correction surgery: $4(12 \%)$

(2) Tightness of Achilles tendon: 2 (6\%)

(3) Isolation exercise was not done properly, which makes toes flexed position: $1(3 \%)$

(4) Need of self care: $1(3 \%)$

9. Overall impression of the present status: Good: 25 cases (76\%), Fair: 4 cases (12\%), Poor: 4 cases $(12 \%)$

${ }^{5}$ Extensor Hallucis Longus

${ }^{6}$ Extensor Digitorum Longus

Table 1. 33 Follow-up cases by method:

\begin{tabular}{|c|c|c|c|c|c|c|c|c|c|c|c|}
\hline Method & Total & Male & Female & $\begin{array}{c}\text { Mean age } \\
\text { at } \\
\text { operation } \\
\text { (years }\end{array}$ & SD & $\begin{array}{c}\text { Dorsi- } \\
\text { flexion } \\
\left({ }^{\circ}\right)\end{array}$ & SD & $\begin{array}{c}\text { Plantar } \\
\text { flexion } \\
\left({ }^{\circ}\right)\end{array}$ & SD & $\begin{array}{c}\text { Range of } \\
\text { Motion } \\
\left({ }^{\circ}\right)\end{array}$ & SD \\
\hline $\begin{array}{c}\text { Interosseous } \\
\text { route }\end{array}$ & 14 & 7 & 7 & $\begin{array}{c}27(13 \sim \\
50)\end{array}$ & 12.7 & $\begin{array}{c}1.8(-10 \\
\sim 25)\end{array}$ & 10.1 & $\begin{array}{c}-10.7(- \\
30 \sim 5)\end{array}$ & 9.8 & $\begin{array}{c}12.5(5 \\
\sim 20)\end{array}$ & 18.3 \\
\hline $\begin{array}{c}\text { Circumtibial } \\
\text { route }\end{array}$ & 19 & 15 & 4 & $\begin{array}{c}48.6(18 \\
\sim 68)\end{array}$ & 14.1 & $\begin{array}{c}9.8(-10 \\
\sim 25)\end{array}$ & 7.5 & $\begin{array}{c}-8.7(-35 \\
\sim 5)\end{array}$ & 11.3 & $\begin{array}{c}18.5(2 \\
\sim 40)\end{array}$ & 10.8 \\
\hline Total & 33 & 22 & 11 & $\begin{array}{c}39.5(13- \\
68)\end{array}$ & 17.2 & $\begin{array}{c}6.6(-10 \\
\sim 10)\end{array}$ & 9.5 & $\begin{array}{c}-9.5(-35 \\
\sim-10)\end{array}$ & 10.6 & $\begin{array}{c}16.0(2 \\
\sim 10)\end{array}$ & 9.0 \\
\hline
\end{tabular}

Table 2. 33 Follow-up cases by sex:

\begin{tabular}{|c|c|c|c|c|c|c|c|c|c|c|c|}
\hline Sex & Total & $\begin{array}{c}\text { Interos } \\
\text { seous } \\
\text { route }\end{array}$ & $\begin{array}{c}\text { Circum } \\
\text { tibial } \\
\text { route }\end{array}$ & $\begin{array}{c}\text { Mean age } \\
\text { (years } \\
\text { old })\end{array}$ & SD & $\begin{array}{c}\text { Dorsi- } \\
\text { flexion } \\
\left({ }^{\circ}\right)\end{array}$ & SD & $\begin{array}{c}\text { Plantar } \\
\text { flexion } \\
\left({ }^{\circ}\right)\end{array}$ & SD & $\begin{array}{c}\text { Range of } \\
\text { Motion } \\
\left({ }^{\circ}\right)\end{array}$ & SD \\
\hline Male & 22 & 7 & 15 & $\begin{array}{c}44.3(14 \\
\sim 68)\end{array}$ & 15.3 & $\begin{array}{c}9.9(-10 \\
\sim 25)\end{array}$ & 7.7 & $\begin{array}{c}-5.2(-30 \\
\sim 5)\end{array}$ & 8.7 & $\begin{array}{c}15.1(2 \\
\sim 30)\end{array}$ & 7.4 \\
\hline Female & 11 & 7 & 4 & $\begin{array}{c}29.7(13 \\
\sim 62)\end{array}$ & 17.2 & $\begin{array}{c}-0.5(-10 \\
\sim 20)\end{array}$ & 9.1 & $\begin{array}{c}-18.2(- \\
35- \\
10)\end{array}$ & 8.7 & $\begin{array}{c}17.7(5 \\
\sim 40)\end{array}$ & 11.9 \\
\hline Total & 33 & 14 & 19 & $\begin{array}{c}39.5(13 \\
\sim 68)\end{array}$ & 17.2 & $\begin{array}{c}6.6(-10 \\
\sim 10)\end{array}$ & 9.5 & $\begin{array}{c}-9.5(-35 \\
\sim-10)\end{array}$ & 10.6 & $\begin{array}{c}16.0(2 \\
\sim 10)\end{array}$ & 9.0 \\
\hline
\end{tabular}




\section{Case Presentation}

Case 1. (Photo 1.) Male, Post TPT for left dropfoot through interosseous route, Age of operation: 14 y.o., Age of assessment: 16 y.o., Follow-up period: 29 months

Findings: Range of Motion of Ankle: $-10^{\circ} \sim-30^{\circ}$, Tension of medial tail: good, Tension of lateral tail: not visible, Alignment of foot: Inverted deformity, Gait: slight step gait, Total impression: poor, Recorrection operation done

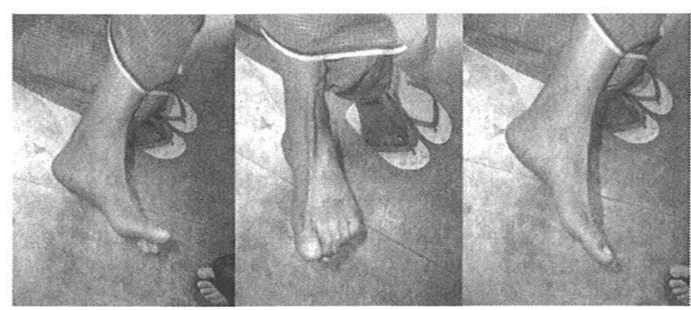

Photo 1.

Case 2. (Photo 2.) Female, Post TPT for left dropfoot through interosseous route, Age of operation: 14 y.o., Age of assessment: 16 y.o., Follow-up period: 27 months

Findings: Range of Motion of Ankle: $0^{\circ} \sim-10^{\circ}$, Tension of medial tail: good, Tension of lateral tail: poor and loosen, Alignment of foot: Inverted deformity, Gait: slight step gait, Total impression: poor, Re-correction operation done

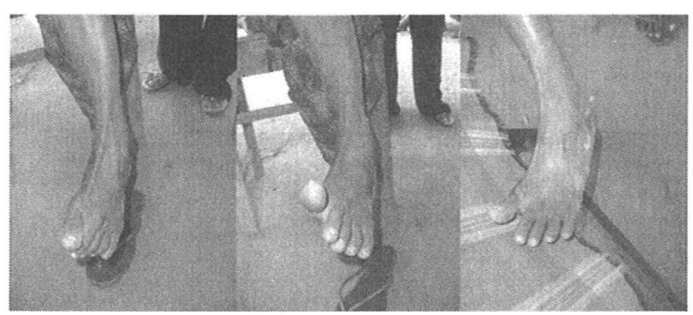

Photo 2.

Case 3. (Photo 3.) Female, Post TPT for right drop-foot through interosseous route, Age of operation: 24 y.o., Age of assessment: 27 y.o., Follow-up period: 38 months

Findings: Range of Motion of Ankle: $-5^{\circ} \sim-20$ ${ }^{\circ}$, Tension of medial tail: less, Tension of lateral tail: good, Alignment of foot: slightly everted when foot is dorsi-flexed, Gait: normal, Total impression: good

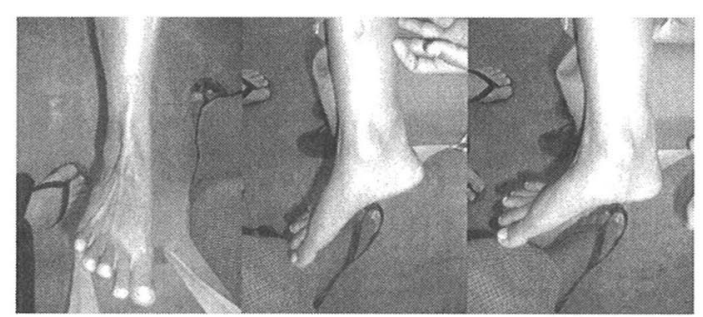

Photo 3.

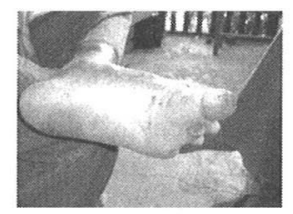

Photo 4.

Only a case of plantar ulcer, post operation 26 months, ROM: $5 \sim 0^{\circ}$, A simple ulcer was present at MP (Metacarpal-Pharangial) joint of 2 nd toe.

\section{Discussion}

Total results of follow-up cases for TPT operation were; good: 25 cases (76\%), fair: 4 cases $(12 \%)$ and poor: 4 cases (12\%). In good and fair cases, patients were satisfied with the results and TPT improved the QOL of patients. 4 cases showed serious inversion deformity with no tension of Extensor Digitorum Longus seen, which were identified as poor results. One case showed moderate inverted deformity and another one slight due to imbalance of tension of two grafted tendons, former was put as a fair result and latter as a good one according to the seriousness of deformity, because minimal inverted deformity did not affect other components including patient's QOL and seemed 
to have good prognosis. Other two cases showed opposite deformity that the tension of Extensor Digitorum Longus has more than that of Extensor Hallucis Longus (Shown as Case 3). AS the imbalance of two grafted tendons in these two cases were not serious and did not seem to affect other components, both counted as good results. Tension imbalance of these cases could have created serious deformity, if it were more. In almost all cases $(32 / 33,97 \%)$ after TPT, patients were observed to be free from plantar ulcers, because one sallow plantar ulcer was seen at MP joint of $2^{\text {nd }}$ toe only in one male case (Photo 4.). There was any plantar ulcer at operation done, which was one of the criteria of operation indication, and no ulcer was seen before finishing post operation physiotherapy and being discharged from hospitals. Patients can get plantar ulcer, both simple and complicated, even TPT operation unless daily routine self care for anesthetic foot is practiced. TPT operation does not guarantee free from plantar ulcer and occurrence of plantar ulcer depends totally on patients' behavior. With enough care and proper foot wear for their feet, patients can only stay away from plantar ulcer even after TPT operation.

Most serious complication of operation (4 cases, $12 \%$ ) identified was inversion deformity due to loosen tension of lateral tail of grafted TP tendon sutured to Extensor Digitorum Longus Tendon. Three among four patients who had this complication were teen-agers and they were the youngest patients among 33 follow up cases. They were three females and one male. Though the reason was unknown, one possible reason might be due to some traumatic accidents such as stumbling over with carelessness to force the operated foot hyperinverted during early days after surgery. Another possible reason might be some weakness of tendon-to-tendon suture between lateral tail of tibialis posterior and extensor digitorum longus, especially in fine tendons of young female cases.

These four cases with inversion deformity got corrected surgically after sometimes of assessment.

\section{Conclusion}

Tibialis Posterior Transfer (TPT) surgery is one of the most important reconstructive surgeries in leprosy. Without correction of drop foot either by surgery or by foot-up splint, toes and forefoot of affected side are getting slow but continuous damages by frequent minor traumas, which may cause foot to get complicated plantar ulcer, loss of toes and shortening of foot. Muscle imbalance due to

Table 3. 4 result poor cases

\begin{tabular}{|c|c|c|c|c|c|c|c|c|c|c|c|}
\hline Sex & $\begin{array}{c}\text { Age of } \\
\text { operation } \\
\text { (years old) }\end{array}$ & $\begin{array}{c}\text { follow up } \\
\text { period } \\
\text { (months) }\end{array}$ & $\begin{array}{c}\text { name of } \\
\text { operatio } \\
n\end{array}$ & Method & $\begin{array}{l}\text { Dorsi- } \\
\text { flexion }\end{array}$ & $\begin{array}{l}\text { Plantar- } \\
\text { flexion }\end{array}$ & ROM & $\begin{array}{c}\text { Tention of } \\
\text { grafted tendon }\end{array}$ & $\begin{array}{c}\text { Alignment } \\
\text { of foot }\end{array}$ & $\left|\begin{array}{l}\text { Planta } \\
\text { r ulcer }\end{array}\right|$ & $\begin{array}{l}\text { Total } \\
\text { results }\end{array}$ \\
\hline$M$ & 14 & 29 & $1-t p t$ & Interosseous & -10 & -30 & 20 & $\begin{array}{c}\text { EHL: Good, } \\
\text { EDL: no tension }\end{array}$ & $\begin{array}{l}\text { Inverted } \\
\text { foot defo. }\end{array}$ & no & poor \\
\hline$F$ & 35 & 29 & $1-t p t$ & circumtibial & -10 & -30 & 20 & EDL: reptured & $\begin{array}{l}\text { Inverted } \\
\text { foot defo. }\end{array}$ & no & poor \\
\hline$F$ & 13 & 28 & r-tpt & Interosseous & -5 & -10 & 5 & $\begin{array}{c}\text { EHL: Good, } \\
\text { EDL: no } \\
\text { tension, }\end{array}$ & $\begin{array}{l}\text { Inverted } \\
\text { foot defo. }\end{array}$ & no & poor \\
\hline $\mathbf{F}$ & 14 & 27 & $1-t p t$ & Interosseous & 0 & -10 & 10 & $\begin{array}{c}\text { EHL: good, EDL: } \\
\text { loosen }\end{array}$ & $\begin{array}{l}\text { Inverted } \\
\text { foot defo. }\end{array}$ & no & poor \\
\hline
\end{tabular}


peroneal nerve palsy may cause fixed inverted foot and talipes equines deformity as a long-term result, unless regular exercise is properly done. Without correction of drop foot either by surgery or by footup splint, other POD measures such as self-care practices and foot wears are not much effective to prevent further damages. Many patients with drop foot had lost their foot because there was no surgical service for drop foot in Myanmar. Since TPT surgery can save the foot and improve QOL very much for life long if self cares are routinely practiced and proper foot wears are regularly provided, it is worth introducing first among other leprosy reconstructive surgery into general health services. For this reason a joint project of JICA and Department of Health, Union of Myanmar on Leprosy Control \& Basic Health Services (4/2000-3/2005) tried to introduce TPT surgery at township level general hospitals in 9-selected townships of MidMyanmar as a component of essential package of POD/POWD, but it seems that expanding TPT surgery as a routine service takes some more time at present because of some inevitable reasons, such as financial issues and frequent replacement of surgeons at district level hospitals. From the results of TPT surgery follow-up, it was learnt that it could benefit much to the patients, if resources and systems permit to make it as a routine service.

\section{References}

1. Bryceson A, Phaltzgraff RE: Leprosy Third Edition, Churchhill Livingstone, 1990.

2. Lwin K, Myint T, Gyi MM, Thein M, Shew $\mathrm{T}$, Sein KN: Leprosy control in Myanmar 1952-2003 -a success story. Lepr Rev 76, 77-86, 2005.

3. Global Strategy for Further Reducing the Leprosy Burden and Sustaining Leprosy Control Ac- tivities (Plan period: 2006-2010), WHO, 2005.

4. Regional Strategy for Sustaining Leprosy Services and Further Reducing the Burden of Leprosy - 2006-2010, WHO SERO 2005; Strategy to Sustain Leprosy Services Following Elimination in Asia and Pacific, WHO SERO \& WPRO, 2005.

5. Fritschi EP: Surgical Reconstruction and Rehabilitation in Leprosy. TLM New Delhi $2^{\text {nd }}$ edition pp165-176, 1984.

6. Anita NH, Enna CD, Daver BM: The Surgical Management of Deformities in Leprosy and Other Peripheral Neuropathies, Oxford University Press, Delhi Calcutta Madras pp106-110, 1992.

7. Ishida Y, Hikita K: JICA Leprosy Control and Basic Health Services Project in Myanmar Nihon Hansenbyo Gakkai Zasshi 74:185-90, 2005.

8. Cross H. A Delphi consensus on criteria for contraindications, assessment indicators and expected outcomes related to tibialis posterior transfer surgery. Int J Lepr Other Mycobact Dis 73:13-21, 2005.

9. Qian JG, Yao WH, Qian CZ: A long-term followup result of posterior tibialis muscle transfer for foot-drop in leprosy patients, Zhongguo Xiu Fu Chong Jian Wai Ke Za Zhi 17:240-1, 2003.

10. Soares D: Tibialis posterior transfer in the correction of footdrop due to leprosy. Lepr Rev 66:229-34, 1995.

11. Soares D: Tibialis posterior transfer for the correction of foot drop in leprosy. Long-term outcome. J Bone Joint Surg Br 78:61-2, 1996.

12. Bari MM, Islam AK, Haque AK: Surgical reconstruction of leprotic foot-drop. Lepr Rev 67:200-2, 1996.

13. Yeap JS, Birch R, Singh D: Long-term results of tibialis posterior tendon transfer for dropfoot. Int Orthop 25:114-8, 2001. 


\title{
ハンセン病による下車足に対する 後陻骨筋移行術の術後成績
}

\author{
石田 裕*1)，Saw Lwin ${ }^{2) ， K y a w ~ M y i n t ~}{ }^{3)}$ \\ 1 ）国立国際医療センター国際医療協力局 \\ 2 ) Rtd. Orthopedic surgeon, National Yenanthar Leprosy Hospital, Mandalay, Union of Myanmar \\ 3 ) National Leprosy Control Programme, Department of Health, Naypyitaw, Union of Myanmar
}

〔受付：2007 年 1 月 31 日、掲載決定：2007 年 4 月 28 日〕

キーワード：下垂足、後脛骨筋移行術、ハンセン病、ミャンマー

\begin{abstract}
ハンセン病による障害の予防・悪化予防のサービスを拡大することは、社会のハンセン病後遺症障害に よる負担軽減に取って重要である。下垂足に対する後脛骨筋移行術（TPT）は、確立された手術法であり、 郡病院レベルで比較的簡単に施行することが出来る。この手術で機能の再建を行うことにより罹患肢障害 の悪化を防止することは、ひいては患者の社会的な負担を軽減することにもつながる。JICAハンセン病対策・ 基礎保健サービス改善プロジェクト（Jan/2002-Jan/2006）は、期間中に 70 例の TPT 手術を人材養成研 修目的で行った。2006 年 11 月に手術成績のフォローアップを中部ミャンマー9タウンシップで行い、こ の内 33 例（男性 22 例、女性 11 例）を調査し得た。フォローアップ期間は、29.1 ケ月（SD=7.1, 10-48 months）であった。結果は、良好 25 例 (76\%)、まずまず：4例（12\%)、不良：4例（12\%）であった。 良好とまずまずの患者は、手術の結果に満足していると答え、TPT は、生活の質を向上すると考えられた。 ほとんどの症例で $(32 / 33,97 \%)$ 足底潰瘍は見られなかった。最も重要な合併症は、長趾伸筋腱に縫合し た外側の後脛骨筋腱の弛みによる足の内反変形 (4 cases, 12\%) であった。TPT 手術成績のフォローアップ の結果は概して良好であり、この手術は下垂足を持つ患者に非常に有益で、資源が許せば多くの場所で通 常の医療サービスとして施行すべきである。
\end{abstract}

\footnotetext{
* Corresponding author:

国立国際医療センター国際医療協力局

于 162-8655 東京都新宿区戸山 1-21-1

TEL : 03-3202-7181 FAX: 03-3205-7860

E-mail :y-ishida@it.imej.go.jp
} 